OPEN ACCESS

Edited by:

Carlos Lodeiro

Universidade Nova de Lisboa,

Portugal

Reviewed by:

Ajay Singh Karakoti, Ahmedabad University, India

Emilia Morallon,

University of Alicante, Spain

*Correspondence:

Gema Martinez

gemamar@unizar.es

Jesus Santamaria

Jesus.Santamaria@unizar.es

Specialty section:

This article was submitted to Nanoscience,

a section of the journa

Frontiers in Chemistry

Received: 03 July 2018 Accepted: 25 September 2018 Published: 16 October 2018

Citation:

Martinez G, Malumbres A, Lopez A,

Mallada R, Hueso $\mathrm{JL}$ and Santamaria J (2018) Laser-Assisted Production of Carbon-Encapsulated Pt-Co Alloy Nanoparticles for Preferential Oxidation of Carbon Monoxide. Front. Chem. 6:487 doi: 10.3389/fchem.2018.00487

\section{Laser-Assisted Production of Carbon-Encapsulated Pt-Co Alloy Nanoparticles for Preferential Oxidation of Carbon Monoxide}

\author{
Gema Martinez ${ }^{1,2 *}$, Ana Malumbres ${ }^{2}$, Angela Lopez ${ }^{2}$, Reyes Mallada ${ }^{1,2}$, Jose L. Hueso ${ }^{1,2}$ \\ and Jesus Santamaria ${ }^{1,2 *}$ \\ ${ }^{1}$ Networking Research Center on Bioengineering, Biomaterials and Nanomedicine, CIBER-BBN, Zaragoza, Spain, \\ ${ }^{2}$ Department of Chemical Engineering, Nanoscience Institute of Aragon (INA), Universidad de Zaragoza, Zaragoza, Spain
}

C-encapsulated highly pure $\mathrm{Pt}_{x} \mathrm{Co}_{y}$ alloy nanoparticles have been synthesized by an innovative one-step in-situ laser pyrolysis. The obtained X-ray diffraction pattern and transmission electron microscopy images correspond to $\mathrm{Pt}_{\mathrm{x}} \mathrm{Co}_{\mathrm{y}}$ alloy nanoparticles with average diameters of $2.4 \mathrm{~nm}$ and well-established crystalline structure. The synthesized $\mathrm{Pt}_{x} \mathrm{Co}_{y} / \mathrm{C}$ catalyst containing $1.5 \mathrm{wt} \%$ of $\mathrm{Pt}_{x} \mathrm{Co}_{y}$ nanoparticles can achieve complete $\mathrm{CO}$ conversion in the temperature range $125-175^{\circ} \mathrm{C}$ working at weight hourly space velocities (WHSV) of $30 \mathrm{~L} \mathrm{~h}^{-1} \mathrm{~g}^{-1}$. This study shows the first example of bimetallic nanoalloys synthesized by laser pyrolysis and paves the way for a wide variety of potential applications and metal combinations.

Keywords: bimetallic alloy, nanoparticles, $\mathrm{Pt}_{\mathrm{x}} \mathrm{Co}_{\mathrm{y}} / \mathrm{C}$ catalyst, laser pyrolysis, preferential $\mathrm{CO}$ oxidation

\section{INTRODUCTION}

Increasing interest is currently being devoted to the use of supported bimetallic alloy and intermetallic nanoparticles as a promising way to modify activity and selectivity, to improve stability and partially substitute expensive noble metals in conventional supported metallic catalysts, such as Pt, Pd, and Rh system (Yu et al., 2012; Furukawa and Komatsu, 2017). In general, the properties of the bimetallic catalysts differ from their monometallic counterparts owing to the synergistic effects of geometry and electronic effects between metals. Therefore, their catalytic performance can be tuned, because an additional degree of freedom, for modifying the geometric and electronic structures is applicable by changing their composition and size (Tao et al., 2012; Wang et al., 2014).

$\mathrm{Pt}_{\mathrm{x}} \mathrm{Co}_{\mathrm{y}}$ alloy is one of the most widely studied bimetallic systems because of its stability and broad catalytic scope (Service, 2002; Stamenkovic et al., 2007; Huang et al., 2017). One of the reactions in which these multimetallic alloys may offer greater benefits than conventional $\mathrm{Pt}$ catalysts is the preferential oxidation (PROX) of carbon monoxide (CO; Liu et al., 2012), a case of substrate-selective oxidation of $\mathrm{CO}$ in excess of hydrogen $\left(\mathrm{H}_{2}\right)$. The main requirements to be fulfilled by the catalysts used in PROX reaction are: (i) high activity at low temperatures achieving $\mathrm{CO}$ conversion to $\mathrm{CO}_{2}$ higher than $99 \%$, (ii) high selectivity to the $\mathrm{CO}$ oxidation reaction, avoiding the oxidation of hydrogen in a wide operation temperature window (e.g., $80-180^{\circ} \mathrm{C}$ ) between the low temperature shift reactor operation around $200^{\circ} \mathrm{C}$ and (iii) the low temperature feed to the PEMFC. Hence the catalyst should not be deactivated by the presence of $\mathrm{CO}_{2}$ and $\mathrm{H}_{2} \mathrm{O}$ in the reformate 
feed stream (Liu et al., 2012). In fact, an improved performance in the catalytic activity for this reaction when using $\mathrm{Pt}_{\mathrm{x}} \mathrm{Co}_{\mathrm{y}}$ alloy catalysts, instead of $\mathrm{Pt} / \mathrm{C}$, is observed as a consequence of the special synergic effect between cobalt and platinum (Yan et al., 2004; Ko et al., 2007; Snytnikov et al., 2007; Wang et al., 2013; Furukawa et al., 2016). The formation of the intermetallic alloy induced an extension of the Pt-Pt atomic distance and electron transfer from Pt to Co. Both effects result in weaker adsorption of $\mathrm{CO}$, compared to the pure metal resulting in higher activity at lower temperature (Komatsu and Tamura, 2008). However, there are still serious limitations in their synthesis, because of the difference in standard reduction potential between the two metals ions and the distinct atom sizes. A challenge is to maintain simultaneously (i) a narrow nanoscale size distribution; (ii) a uniform composition throughout the nanoparticles; (iii) a fully alloyed degree, and (iv) high dispersion on the support, which represents a serious challenge in conventional synthesis approaches.

Routine synthesis approaches typically involve the impregnation of an already synthesized carbon-supported Pt metal catalyst with a second metal precursor salt, followed by alloying at high temperatures $\left(\geq 900^{\circ} \mathrm{C}\right)$ under inert gas or reducing conditions (Tamizhmani and Capuano, 1994; Min et al., 2000; Takenaka et al., 2010). Nevertheless, this thermal treatment gives rise to undesired particle growth by sintering and coalescence of the particles with the concurrent increase of average particle size, resulting in a lower catalysts active area (Antolini, 2003). As an alternative to overcome these problems, other procedures such as reduction of Pt and the second metal at low temperature (Xiong et al., 2002), micro emulsion methods (Xiong and Manthiram, 2005) or polyol methods (Jang et al., 2011) are aimed to synthesize bimetallic nanoparticles under milder conditions. However, these methods offer low alloying degree (Zignani et al., 2008; Jang et al., 2011; Vinayan et al., 2012; Lopez et al., 2016), mainly because the formation of alloyed intermetallic phases generally needs high temperatures(Furukawa and Komatsu, 2017). In addition, these processes require longer synthesis time (including cleaning protocols) and deployment on supports.

Alternatively, multimetallic nanoparticles have been also produced in gas phase by procedures such as flame pyrolysis (Strobel et al., 2005), laser ablation (Senkan et al., 2006) or plasma-assisted dissociation of organometallic vapor (Lin and Sankaran, 2011; Saedy et al., 2017). Unfortunately, these gas-phase approaches have also suffered from excessive particle growth and aggregation, reducing the surface area and number of actives sites (Rodriguez et al., 2011; Wang and Li, 2011). Therefore, in order to preserve the catalytic properties of the nanoparticles, particle agglomeration must be prevented. For this purpose, encapsulating shells appear as a promising and elegant strategy. Among these encapsulating candidates, carbon offers many advantages, such as high stability under various physical and chemical conditions, high electrical conduction for electrochemical applications, and low manufacturing cost. Various techniques for carbon encapsulation of metal nanoparticles have been investigated including laser ablation of organometallic targets (Munoz et al., 2010; Seral-Ascaso et al.,
2013), solution plasma processes (Kang et al., 2013), one-step pyrolysis using cyanamide and metal salts as precursor (Han et al., 2015) or one-pot light-assisted evaporation induced selfassembly approach (Ghimbeu et al., 2015). Unfortunately, most of them render broad particle size distribution or at least less controllable and limited availability of control in stoichiometry requirements, making them very restricted methods for the synthesis of alloy nanoparticles.

Therefore, further developments are still needed in order to design a versatile one-pot synthesis that allows high nanoparticle dispersion, tuneable stoichiometry and at the same time preserving small particle size and achieving good alloying and stability. In this work, we propose a simple one-pot synthesis method for alloying nanoparticles containing $\mathrm{C}$ shells, based on laser pyrolysis processing. Previous studies in our group have shown that this technique could be used to successfully synthesize a variety of nanoparticles with extremely high purity (Martínez et al., 2012; Malumbres et al., 2015). Although most of the research in this area is limited to metal precursors which are gases or liquid having sufficient vapor pressure at moderate temperature, which restricts its application to certain elements or makes necessary to synthesize specific organometallic precursors or even use highly flammable and toxic precursors as it is the case of silane for the synthesis of Si nanoparticles. Recently, much attention is being focused on the interaction between the laser beam and the aerosols droplets containing solid precursors, that may expand the application of the technique to all the elements as far as their salts are soluble in sprayable solvents (Wang et al., 2017). The most important merits of laser pyrolysis processing include the well-defined interaction volume, spatial uniformity of the reaction zone, short millisecond scale residence times, high heating/cooling rates, the fact that the nanoparticles properties can be tuned by adjusting the process parameters, the continuous nature that avoids the intrinsic variability of batch processing and the high purity of the prepared materials.

In this paper we present a flexible and continuous $\mathrm{Pt}_{\mathrm{x}} \mathrm{Co}_{\mathrm{y}} / \mathrm{C}$ catalysts synthesis, which is much more time and cost saving than current multi-step processes. As far as we are concerned this is the first time that bimetallic nanoparticles have been synthesized by laser pyrolysis. The innovative, versatile, and continuous single step strategy involves interaction between the laser beam and the organometallics precursors in a liquid spray form. The role of the solvent it is not only to transport the solid metal precursors at the reaction zone but also to provide the source to form the carbon framework avoiding agglomerating of the particles. By carefully combining precursor's ratio, bimetallic nanoparticles of controlled composition can be tailored by this approach. The chemical and structural characterization of the synthesized material revealed that the obtained $\mathrm{Pt}_{\mathrm{x}} \mathrm{Co}_{\mathrm{y}}$ alloy nanoparticles were encapsulated in $\mathrm{C}$ matrix and exhibited a uniform size distribution, average diameters below $3 \mathrm{~nm}$, and high crystallinity. Finally, the $\mathrm{Pt}_{\mathrm{x}} \mathrm{Co}_{\mathrm{y}} / \mathrm{C}$ (Pt:Co, 3:1) nanoparticles were deposited on a ETS-10 microporous support (1.5 wt.\% $\mathrm{Pt}_{\mathrm{x}} \mathrm{Co}_{\mathrm{y}} / \mathrm{C}$ ) and their catalytic activity was tested in PROX reaction feeding a simulated steam reforming stream $(1 \% \mathrm{CO}$, $21 \% \mathrm{CO}_{2}, 3 \% \mathrm{H}_{2} \mathrm{O}, 1 \% \mathrm{O}_{2}$, and $\mathrm{H}_{2}$ balance). 


\section{MATERIALS AND METHODS}

\section{Chemicals}

Platinum (II) acetylacetonate [Pt(acac) $2,97 \%]$, cobalt (III) acetylacetonate $\left[\mathrm{Co}(\mathrm{acac})_{3}, 99.99 \%\right]$, toluene $(99.5 \%)$ and absolute ethanol ( $\geq 98 \%)$ were supplied from Sigma Aldrich and used without further purification.

\section{$\mathrm{Pt}_{\mathrm{x}} \mathrm{Co}_{\mathrm{y}} / \mathrm{C}$ Composite Nanoparticles Synthesis}

The synthesis of $\mathrm{Pt}_{\mathrm{x}} \mathrm{Co}_{\mathrm{y}} / \mathrm{C}$ composite nanoparticles with different compositions has been carried out by laser pyrolysis in a continuous flow reactor described elsewhere (Martínez et al., 2012; Malumbres et al., 2013, 2015). The starting solution employed for the synthesis of $\mathrm{Pt}_{\mathrm{x}} \mathrm{Co}_{\mathrm{y}} / \mathrm{C}$ was prepared by dissolving $\mathrm{Pt}(\mathrm{acac})_{2}(47 \mathrm{mg}, 0.12 \mathrm{mmol})$ and the corresponding amount of $\mathrm{Co}(\mathrm{acac})_{3}[11 \mathrm{mg}(0.04 \mathrm{mmol})$ or $30 \mathrm{mg}(0.12 \mathrm{mmol})]$ in toluene, to get a molar ratio $\mathrm{Pt}: \mathrm{Co}=3$ or $\mathrm{Pt}: \mathrm{Co}=1$. The technique is based on the interaction between the laser beam (Rofin SCx30, $\lambda=10.6 \mu \mathrm{m}$ ) at $100 \mathrm{~W}$ power and the starting materials in a liquid spray form (aerosol). Sulfur hexafluoride $\left(\mathrm{SF}_{6}\right)$ was added as sensitizer gas. The liquid mixture was introduced in the reactor by a syringe pump working at $15 \mathrm{ml} / \mathrm{h}$. The aerosol spray was produced by a nebulizer immediately located before the chamber. Aerosol droplets were transported in a flow of $\mathrm{Ar} / \mathrm{SF}_{6}, 130$ and $30 \mathrm{sccm}$, respectively, into the reaction chamber through a $1 / 4$ inch inner diameter nozzle. A flow of hydrogen $(10 \mathrm{sccm})$ and argon $(100 \mathrm{sccm})$ was used as coaxial gas flow to confine the reaction in a very small volume without any interaction with reactor walls. The aerosol and laser beam are designed to intersect orthogonally, and the beam diameter $\left(\mathrm{d}_{\text {laser }}\right)$ and the aerosol spray diameter $\left(\mathrm{d}_{\text {spray }}\right)$ were controlled in such way that $\mathrm{d}_{\text {spray }}<\mathrm{d}_{\text {laser }}$. This configuration ensured that all the spray molecules were confined within the beam area to complete the pyrolysis (see Scheme 1). In order to prevent powder deposition onto the vertical and horizontal windows they were continuously flushed with 600 and $200 \mathrm{sccm}$ of Ar and $\mathrm{N}_{2}$, respectively. The pressure was maintained constant at 200 mbar through a diaphragm valve located between the reaction chamber and the vacuum pump. The gas flows were controlled by mass flow controllers. The reaction proceeded with color change from green light (color of the precursor solution) to black (color of the nanostructures powder obtained). To capture and isolate nanoparticles, the freshly nucleated particles were directly collected onto cellulose filters (F2044). Typical values and ranges of the experimental parameters are listed in Table $\mathbf{1 .}$ This work has been performed by the ICTS "NANBIOSIS" by the Synthesis of Nanoparticles Unit of the CIBER in Bioengineering, Biomaterials \&Nanomedicine (CIBER-BBN) at the Institute of Nanoscience of Aragon (INA)-Universidad de Zaragoza.

\section{Structural Characterization}

A battery of techniques was used to characterize the $\mathrm{Pt}_{\mathrm{x}} \mathrm{Co}_{\mathrm{y}} / \mathrm{C}$ composite nanoparticles. Particle morphology and size distribution were determined by a FEI Tecnai thermoionic

TABLE 1 | Experimental parameters for the optimized synthesis of carbon-encapsulated $\mathrm{Pt}_{\mathrm{x}} \mathrm{Co}_{\mathrm{y}}$ bimetallic nanoparticles.

\section{Synthesis conditions}

Flow rate of windows gases (sccm)

Flow rate of coaxial gas $\mathrm{Ar} / \mathrm{H}_{2}$ (sccm)

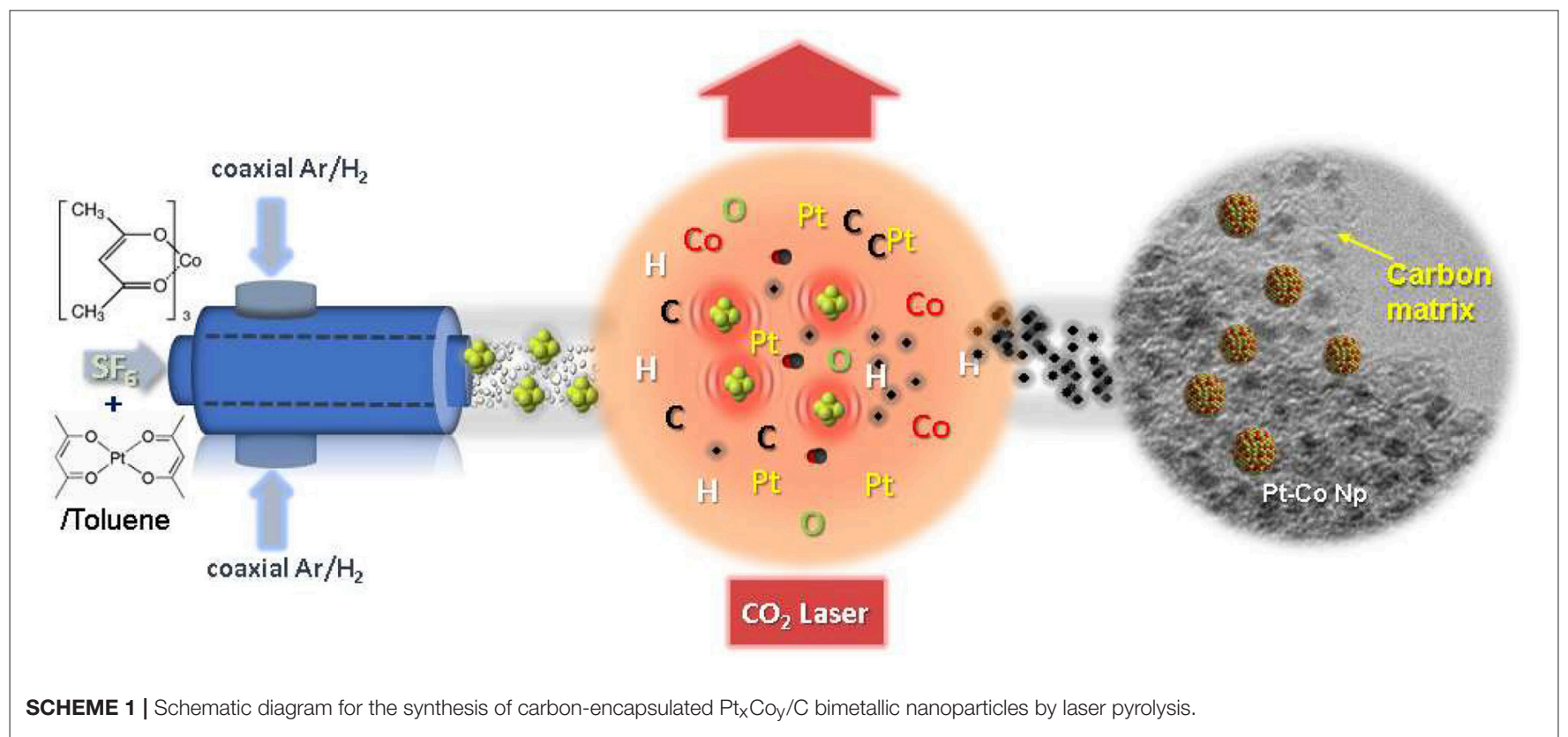


transmission electron microscopy (TEM) operated at $200 \mathrm{kV}$. More than 200 particles were measured to evaluate the mean diameter. The data were fitted with a normal distribution function and the standard deviation was obtained for all the samples. To determine the crystalline structure and the composition of the particles, High Resolution Transmission Electron Microscope (HRTEM), Scanning Transmission Electron Microscope with high angle annular dark field (STEM-HAADF) and Energy Dispersive X-ray Spectroscopy (EDS) analysis were performed by using a FEI TECNAI F30 and FEI Titan ${ }^{\mathrm{TM}}$ Cube $(80-300 \mathrm{kV})$ microscopes at an acceleration voltage of $300 \mathrm{kV}$. To prepare the sample, $10 \mu \mathrm{L}$ of a ethanol particle suspension were dropcasted on a lacey carbon TEM grid. Powder X-ray diffraction (XRD) analyses were performed in a Rigaku/Max System diffractometer with $\mathrm{Cu} \mathrm{K} \alpha$ radiation source $(\lambda=0.15418 \mathrm{~nm})$. Surface composition was analyzed by X-ray photoelectron spectroscopy (XPS) with an Axis Ultra DLD (Kratos Tech.) The spectra were excited by a monochromatic $\mathrm{Al} \mathrm{K \alpha}$ source $(1486.6 \mathrm{eV})$ run at $12 \mathrm{kV}$ and $10 \mathrm{~mA}$ and pass energy of $20 \mathrm{eV}$ was used. The binding energies were referenced to the internal C $1 \mathrm{~s}(284.6 \mathrm{eV})$ standard. Analysis of the peaks was performed with CasaXPS software, using a weighted sum of Lorentzian and Gaussian component curves after Shirley background subtraction. To characterize the carbon shell of the nanoparticles, Raman spectra were obtained with a Laser Raman WiTec Alpha 300 spectrometer, with the $532 \mathrm{~nm}$ line of an $\mathrm{Ar}^{+}$ion laser. The bulk chemical composition of digested samples was analyzed using microwave plasma atomic emission spectroscopy (Agilent 4100 MP-AES).

\section{Catalytic Activity Tests}

The as synthesized $\mathrm{Pt}_{\mathrm{x}} \mathrm{Co}_{\mathrm{y}}$ nanoparticles were incorporated to the microporous titanosilicates ETS-10 support by incipient wetness impregnation method, to get 1.5 wt. $\% \mathrm{Pt}_{\mathrm{x}} \mathrm{Co}_{\mathrm{y}}$, following our previous protocol (Lopez et al., 2016). The activity measurements were carried out in an experimental set-up described elsewhere (Lopez et al., 2016). The supported catalyst, $100 \mathrm{mg}$ together with $200 \mathrm{mg}$ of quartz, used as diluent, was loaded in a quartz tube of $9 \mathrm{~mm}$ internal diameter. The reaction temperature was measured with a thermocouple located in the center of the catalyst bed. The composition of the feed stream was: $1 \% \mathrm{CO}, 1 \% \mathrm{O}_{2}, 3 \%$ $\mathrm{H}_{2} \mathrm{O}, 21 \% \mathrm{CO}_{2}$, and hydrogen balance. The feed flow was 50 STP $\mathrm{mL} / \mathrm{min}$ which corresponds to a (weight hourly space velocity) $\mathrm{WHSV}=30 \mathrm{~L} \mathrm{~h}^{-1} \mathrm{~g}^{-1}$. Prior to catalytic activity tests, the solids were heated in air at a heating rate of $5^{\circ} \mathrm{C} / \mathrm{min}$, up to $500^{\circ} \mathrm{C}$ and kept at this temperature for $3 \mathrm{~h}$. Then the catalyst was cooled down to room temperature under $\mathrm{N}_{2}$ atmosphere. Feed and products were analyzed by gas chromatography with a Varian CP-4,900 Micro-GC equipped with two modules containing, molecular sieve and Pora PLOT Q columns, respectively and using helium as carrier gas. Under the analysis conditions the detection limit of $\mathrm{CO}$ was $5 \mathrm{ppm}$.

The CO conversion and the selectivity for the PROX reaction were calculated according to:

$$
X_{c o}=\frac{F_{C O \text { feed }}-F_{C O \text { outlet }}}{F_{\text {CO outlet }}}
$$

$$
S_{\mathrm{co}_{2}}=\frac{2\left(F_{\mathrm{CO} \text { feed }}-F_{\mathrm{CO} \text { outlet }}\right)}{\left(F_{\mathrm{O}_{2} \text { feed }}-F_{\mathrm{O}_{2} \text { outlet }}\right)}
$$

Being $F_{i}$ the corresponding molar flow of each component. The conversion values were obtained after the reactor temperature was stable for at least $30 \mathrm{~min}$. and the reported values represent the average of 3 samples taken at the reactor exit. $\mathrm{CH}_{4}$ was not detected in any of the experiments carried out. The $\mathrm{C}$ mass balance was measured and was always in the range $98-102 \%$.

\section{RESULTS AND DISCUSSION \\ Synthesis and Characterization of Pt-Co Nanoalloys}

As a first step toward accessing carbon dispersed bimetallic alloy nanoparticles, we separately studied the conversion of individual acetylacetonate metal precursors $\left[\mathrm{Pt}(\mathrm{acac})_{2}\right.$ and $\left.\mathrm{Co}(\mathrm{acac})_{3}\right]$ into the corresponding monometallic nanoparticles. Figure S1 indicates that both organometallics precursors were successfully decomposed under similar experimental conditions (Table 1 in experimental section) to yield highly uniform and well-dispersed monometallic nanoparticles within a carbonaceus matrix. The nanoparticles are characterized by spherical shapes, narrow size distributions and particles diameters from $\sim 2.5$ to $3.5 \mathrm{~nm}$.

Once the experimental conditions, for the pyrolysis of the aerosol, were established, the synthesis of $\mathrm{Pt}_{\mathrm{x}} \mathrm{Co}_{\mathrm{y}} / \mathrm{C}$ composite nanoparticles was accomplished by one-step pyrolysis of a toluene solution containing a mixture of both $\mathrm{Pt}(\mathrm{acac})_{2}$ and $\mathrm{Co}(\mathrm{acac})_{3}$ precursors in the required stoichiometric amount. As illustrated in Scheme 1, the fabrication process involves interaction between the laser beam and the starting materials in a toluene spray. When the laser beam intersects the $\mathrm{SF}_{6} /$ Ar nebulized toluene solution reactant stream, a fast-atomic decomposition of the organometallic precursors is produced into the reaction area resulting in the formation of well-dispersed $\mathrm{Pt}_{\mathrm{x}} \mathrm{Co}_{\mathrm{y}}$ bimetallic nanoparticles within a carbonaceous shell.

Figure 1A shows the TEM image and particle size distribution (inset Figure 1A) of the $\mathrm{Pt}_{\mathrm{x}} \mathrm{Coy} / \mathrm{C}$ obtained nanoparticles when the molar ratio of $\mathrm{Pt}$ to $\mathrm{Co}$ precursors was 3 . The TEM image (Figure 1A) reveals that numerous individual nanoparticles with mean size of $2.4 \pm 0.3 \mathrm{~nm}$ (inset) are well dispersed and perfectly C-encapsulated. Figure 1B shows a STEM-HAADF image (the contrast depends directly on the atomic number $\mathrm{Z}^{2}$ ), where the bright bimetallic nanoparticles are easily spotted against the $\mathrm{C}$ matrix. The nanocrystals appear as well-crystallized spherical particles. The semi-quantitatively chemical composition of the nanoparticles was determined by energy-dispersive X-ray (EDX) spectroscopy (Figure 1C). The analysis of the elemental distribution within a single nanoparticle (selected area on Figure 1B) corroborates the coexistence of both $\mathrm{Pt}$ and $\mathrm{Co}$ with atomic percentages of $79.5 \pm 0.7$ and $20.5 \pm 0.5 \%$, respectively. The EDS also shows high resolution 2D mapping of elemental Pt and Co (Figure 1D), which are homogeneously distributed throughout the entire nanoparticle. The bulk composition of the sample determined by Inductively coupled plasma (ICP) further confirmed an overall atomic ratio $\mathrm{Pt}: \mathrm{Co}$ of $3.97 \pm 0.04$. The experimental ratios $(\mathrm{Pt}: \mathrm{Co}=4)$ determined by both measurements matched very 

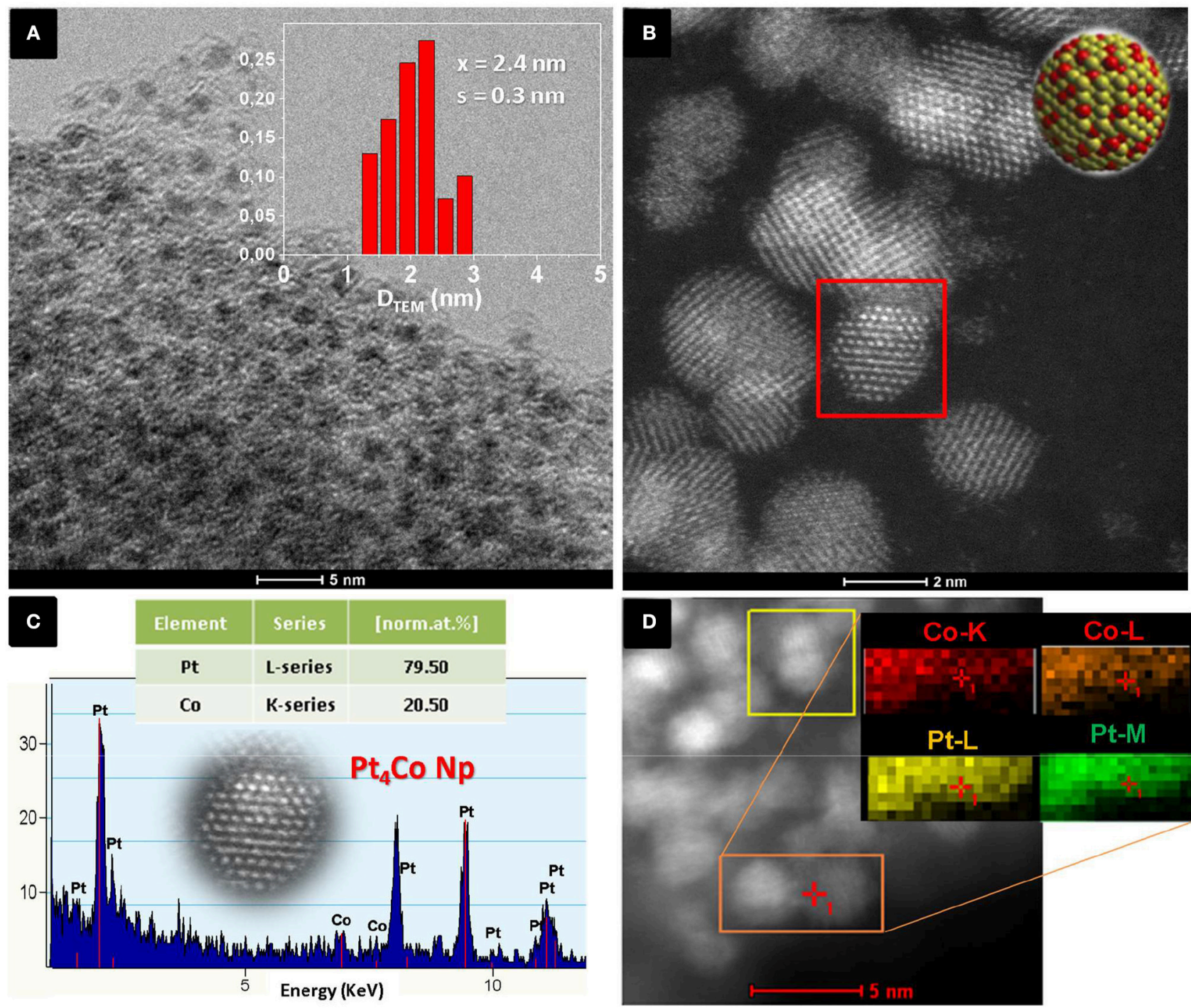

FIGURE 1 | (A) Representative TEM image of $\mathrm{Pt}_{4}$ Co nanoparticles encased in a C matrix, (inset) Particle size histogram, (B) STEM-HAADF image of the Pt 4 Co/C nanoparticles synthesized when the molar ratio of starting Pt:Co precursors is set to 3, (C) EDX analysis of an individual particle (selected area in B) indicating an experimental atomic ratio of $\mathrm{Pt}$ to $\mathrm{Co}$ of $\sim 4\left(\mathrm{Pt}_{4} \mathrm{Co} / \mathrm{C}\right)$, and (D) EDS mapping of elemental Pt (green) and Co (red) with corresponding STEM-HAADF image of the $\mathrm{Pt}_{4} \mathrm{Co} / \mathrm{C}$ composite nanoparticles.

well and were slightly higher than expected from the initial molar ratio fed to the reactor $(\mathrm{Pt}: \mathrm{Co}=3)$. The Pt-enrichment of the as-prepared $\mathrm{Pt}_{4} \mathrm{Co} / \mathrm{C}$ composite nanoparticles can be tentatively attributed to different physicochemical features, such as different decomposition temperature of the organometallic acetylacetonates (Vonhoene et al., 1958). On the other hand, carbon is segregated and deposits as a mixture of amorphous carbon with randomly distributed graphitic domains, confirmed by Raman spectroscopy (Figure S2). The peak centered at 1.595 $\mathrm{cm}^{-1}$ (G-band) is assigned to graphite (Ferrari, 2007), while the peak at $1.348 \mathrm{~cm}^{-1}$ is the D-band mainly derived from the disordered carbon structures (Arbizzani et al., 2011; Liu et al., 2015).

By indexing X-ray diffraction (XRD) pattern (Figure 2A), we examined the crystalline structure of the $\mathrm{Pt}_{4} \mathrm{Co} / \mathrm{C}$ composite nanoparticles. The XRD diffraction peaks are slightly shifted toward higher $2 \theta$ values compared to those of the cubicface centered crystalline Pt (JCPDS card. No. 87-0646), peaks at $40.68^{\circ}, 47.52^{\circ}, 68.84^{\circ}$, and $82.36^{\circ}$, corresponding to the (111), (200), (220), and (311) planes, without any additional peak indicating that the $\mathrm{Pt}_{4} \mathrm{Co} / \mathrm{C}$ catalyst maintains the facecentered cubic ( $\mathrm{fcc}$ ) structure of platinum. This shift can be due to the lattice contraction that occurs when larger $\mathrm{Pt}$ atoms are progressively substituted by smaller Co atoms, thus demonstrating the formation of bimetallic alloy nanoparticles (Xiong and Manthiram, 2004; Salgado et al., 2005; Huang et al., 2006; Jiang et al., 2009; Xia et al., 2015). Moreover, diffraction signals that could be associated to the presence of crystalline cobalt (JCPDS card. No. 01-1277) or its oxides have not been observed for the prepared binary $\mathrm{Pt}_{4} \mathrm{Co} / \mathrm{C}$ composite 

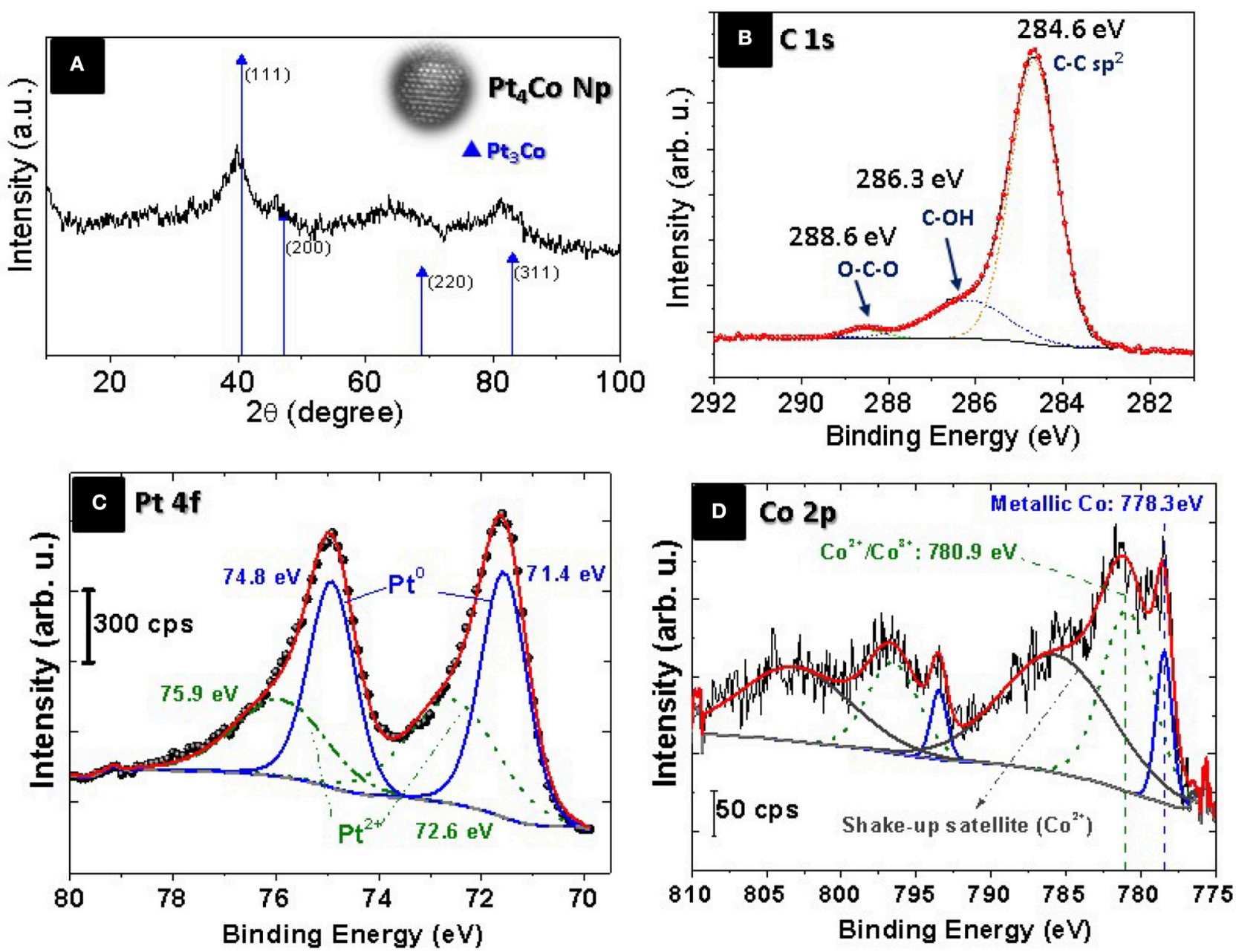

FIGURE 2 | (A) XRD patterns of $\mathrm{Pt}_{4} \mathrm{Co} / \mathrm{C}$ composite nanoparticles, and XPS spectra of: (B) C 1s region, (C) Pt $4 \mathrm{f}$ region and (D) Co 2p region showing the oxidation states of the $\mathrm{Pt}$ and $\mathrm{Co}$ in the $\mathrm{Pt}_{4} \mathrm{Co} / \mathrm{C}$ composite nanoparticles.

nanoparticles. The cobalt contents within the $\mathrm{Pt}_{4} \mathrm{Co} / \mathrm{C}$ sample derived from the Vergad's law (Santiago et al., 2007) was calculated by comparing the lattice parameter obtained from the measured (111) $2 \theta$ Bragg peak $\left(a_{\exp }=0.3850 \mathrm{~nm}\right)$ with those of the metallic Pt ( $a=0.39231 \mathrm{~nm}$; Swanson and Eleanor, 1953 ) and metallic cobalt ( $a=0.35441 \mathrm{~nm}$; Owen and Jones, 1954), respectively. The Co atomic content in the alloy, as determined by this XRD measurement, was about $19.3 \%$. This is close to the nominal content $20 \%$, detected by ICP and EDX analysis.

The oxidation states of $\mathrm{Pt}_{4} \mathrm{Co} / \mathrm{C}$ catalyst were studied by $\mathrm{X}$ ray photoemission spectroscopy (XPS). The survey XP-spectrum reveals the presence of carbon, cobalt, platinum and oxygen. The high-resolution C 1s spectrum is depicted in Figure 2B. The relative intensity of the peaks indicates primarily graphitic carbon $\mathrm{C}-\mathrm{C} / \mathrm{C}=\mathrm{C}(284.6 \mathrm{eV})$ with small percentage of oxidized carbon as $\mathrm{C}-\mathrm{O}$ and $\mathrm{C}=\mathrm{O}$ species $(286.3$ and $288.6 \mathrm{eV}$ ), respectively (Arico et al., 1995). The analytical peaks related to Pt 4 f orbitals and $2 \mathrm{p}$ orbitals for Co are shown in Figures $2 \mathrm{C}, \mathrm{D}$, respectively.
The binding energies (BE) of 74.8 and $71.4 \mathrm{eV}$ in Figure 2C correspond with $\mathrm{Pt} 4 \mathrm{f}_{5 / 2}$ and $\mathrm{Pt} 4 \mathrm{f}_{7 / 2}$, respectively, which can be splitted into two pairs of doublets: metallic Pt at 74.8 and $71.4 \mathrm{eV}$, while the second contribution at 75.9 and $72.6 \mathrm{eV}$ correspond to $\mathrm{Pt}^{2+}$ species (Zsoldos and Guczi, 1992; Zheng et al., 2014a,b). The XPS signals in the Co $2 \mathrm{p}_{3 / 2}$ region (Figure $2 \mathrm{D}$ ) reveal the presence of Co (0) at $778.5 \mathrm{eV}$ shifted $0.4 \mathrm{eV}$ toward higher $\mathrm{BE}$ in Pt-Co alloys compared with the monometallic cobalt phase at $778.1 \mathrm{eV}$ ) which is another confirmation of the formation of the $\mathrm{Pt}_{3} \mathrm{Co}$ alloy nanoparticle (Bardi et al., 1990). A Co $2 \mathrm{p}_{3 / 2}$ peak contribution at $780.9 \mathrm{eV}$ can be assigned to both Co surface phase and $\mathrm{Co}$ oxide $\left(\mathrm{Co}^{2+} / \mathrm{Co}^{3+}\right.$; Zsoldos and Guczi, 1992). Although, the Co $2 \mathrm{p}_{3 / 2}$ peaks are clearly accompanied by strong shake-up satellites, which are characteristic of $\mathrm{CoO}\left(\mathrm{Co}^{+2}\right)$, at $5 \mathrm{eV}$ higher than its main peak, as well as a spin-orbit coupling of around $15.5 \mathrm{eV}$ (Zsoldos and Guczi, 1992) the presence of $\mathrm{Co}_{3} \mathrm{O}_{4}\left(\mathrm{Co}^{3+}\right)$ cannot completely be ruled (Jimenez et al., 1995; Hueso et al., 2008). The low metallic Co content compared to the higher metallic Pt content confirms the oxide-cleansing 
action of Co addition (Arico et al., 2001). The electronegativity difference between Co and Pt (1.8 and 2.2, respectively; Shukla et al., 1999) implies an electron-drawing effect from Pt to the neighboring Co atoms, which make the latter more difficult to reduce.

To demonstrate the versatility and robustness of this synthesis method, we performed the one-step laser-driven pyrolysis of a toluene solution containing a mixture of both $\mathrm{Pt}(\mathrm{acac})_{2}$ and $\mathrm{Co}(\mathrm{acac})_{3}$ precursors in molar ratio of 1 . The structure of the as-prepared $\mathrm{Pt}_{\mathrm{x}} \mathrm{Co}_{\mathrm{y}} / \mathrm{C}$ composite nanoparticles was characterized by TEM (Figure S3A) and STEM-HAADF (Figure S3C). The corresponding micrographs show highly crystalline spherical nanoparticles with average size of 2.3 $\pm 0.4 \mathrm{~nm}$ (Figure S3B) which are well-dispersed across the $\mathrm{C}$ matrix. The coexistence of $\mathrm{Pt}$ and Co elements in the particles is also demonstrated by the EDS analysis with the bimetallic composition of $55.5 \%$ and $44.5 \%$, respectively (Figure S3D). The shift of XRD lines indicates proper alloying (Figure S4). Additional characterization by Raman and X-ray photoemission spectroscopy is provide in Figure S5. These results contributed to demonstrate that the proposed laserassisted synthesis method is a general and feasible route for the synthesis of well dispersed, stable and highly pure Cencapsulated $\mathrm{Pt}_{\mathrm{x}} \mathrm{Co}_{\mathrm{y}}$ bimetallic nanoparticles. The nanoparticles were properly alloyed, while different stoichiometric ratios could be easily tuned by changing the the molar ratio of Pt and Co precursors.

\section{PROX Catalytic Tests}

A systematic evaluation of the catalytic capability of the PtCo alloy nanoparticles was performed after deployment onto an ETS-10 support. The preferential oxidation of CO in the presence of a hydrogen excess was thoroughly evaluated and compared with analogous bimetallic compositions available in the literature (Table 2). The evolution of CO conversion and selectivity as a function of temperature is presented in Figure 3A. The decrease in $\mathrm{CO}$ conversion at higher temperatures occurs due to oxygen scarcity caused by a surface fully covered with chemisorbed hydrogen and acceleration of undesirable concurrent hydrogen oxidation reaction which results in selectivity decrease. The carbon monoxide starts to convert at $50^{\circ} \mathrm{C}$ following a typical light-off curve and the total conversion is achieved at $125^{\circ} \mathrm{C}$, which maintains constant in a temperature window of $50^{\circ} \mathrm{C}$. The PROX unit is located between the outlet of the low temperature water gas shift reactor, working at $200^{\circ} \mathrm{C}$, and the inlet of the fuel cell operating in the range of $80-120^{\circ} \mathrm{C}$, in the case of low temperature proton exchange membrane fuel cell (PEMFC). Table 2 shows the operation temperature window reported by other authors, who synthesized bimetallic Pt-Co NPs by different methods. Except in the case of (Komatsu and Tamura, 2008), the highest temperature windows encountered in the literature,

TABLE 2 | Comparison with literature data for bimetallic PtCo, including composition, preparation method, characterization of intermetallic phases and temperature operation window.

\begin{tabular}{|c|c|c|c|c|c|}
\hline References & $\begin{array}{l}\text { Catalyst composition } \\
\text { metal load } \\
\% \text { wt. }\end{array}$ & Preparation method & Active phases reported & $\begin{array}{l}\text { WHSW } \\
\left(\mathrm{g} \mathrm{h}^{-1}\right)\end{array}$ & $\begin{array}{c}\text { Temperature } \\
\text { operating window }\end{array}$ \\
\hline Yan et al., 2004 & $3 \% \mathrm{Pt} 1 \% \mathrm{Co} / \gamma-\mathrm{Al}_{2} \mathrm{O}_{3}$ & $\begin{array}{l}\text { Sequential impregnation method Pt } \\
\text { followed by Co. In both cases after } \\
\text { impregnation calcination and } \\
\text { reduction steps. }\end{array}$ & $\begin{array}{l}\mathrm{Pt}_{3} \text { Co phase identified by } \\
\text { XRD }\end{array}$ & 40 & $120-160^{\circ} \mathrm{C}$ \\
\hline Ko et al., 2007 & $\begin{array}{l}0.5 \% \mathrm{Pt}-\mathrm{Co} / \mathrm{YSZ} \\
(\mathrm{Co} / \mathrm{Pt}=5)\end{array}$ & $\begin{array}{l}\text { Sequential impregnation method Pt } \\
\text { followed by Co. In both cases after } \\
\text { impregnation calcination and } \\
\text { reduction steps. }\end{array}$ & $\begin{array}{l}\text { TEM: Isolated Pt-Co and Co } \\
\text { nanoparticles. No XRD or } \\
\text { XPS available }\end{array}$ & 60 & $100-120^{\circ} \mathrm{C}$ \\
\hline Snytnikov et al., 2007 & $2 \%(\mathrm{Co}-\mathrm{Pt}) / \mathrm{C}$ & $\begin{array}{l}\text { Sequential impregnation of } \mathrm{Pt} \text { and } \mathrm{Co} \\
\text { salts to obtain } \\
{\left[\mathrm{Co}\left(\mathrm{NH}_{3}\right)_{5} \mathrm{NO}_{2}\right]\left[\mathrm{Pt}\left(\mathrm{NO}_{2}\right)_{4}\right] 1.5 \mathrm{H}_{2} \mathrm{O}} \\
\text { followed by reduction in } \mathrm{H}_{2}\end{array}$ & $\begin{array}{l}\mathrm{Co}_{0.5} \mathrm{Pt}_{0.5} \text { phase identified } \\
\text { by XRD }\end{array}$ & N.A. & $120-150^{\circ} \mathrm{C}$ \\
\hline $\begin{array}{l}\text { Komatsu and Tamura, } \\
2008\end{array}$ & $\begin{array}{l}\mathrm{Pt}_{3} \mathrm{Co} / \mathrm{SiO}_{2} \\
(3 \% \mathrm{Pt} \text { and } \mathrm{Pt} / \mathrm{Co}=3)\end{array}$ & Co-impregnation method & $\begin{array}{l}\mathrm{Pt}_{3} \text { Co phase identified by } \\
\text { XRD }\end{array}$ & 8.4 & $180^{\circ} \mathrm{C}$ \\
\hline Wang et al., 2013 & $\begin{array}{l}\text { Pt-Co/AlPO-5 } \\
(1 \% \mathrm{Pt}-2 \% \mathrm{Co})\end{array}$ & Co-impregnation method & $\begin{array}{l}\text { EDX analysis of Pt-Co, } \\
\text { presence of both metals }\end{array}$ & 24 & $110-125^{\circ} \mathrm{C}$ \\
\hline Furukawa et al., 2016 & $\begin{array}{l}\mathrm{Pt}_{3} \mathrm{Co} / \mathrm{MgO} \\
(3 \mathrm{wt} \%, \mathrm{Pt}, \mathrm{Pt} / \mathrm{Co}=3)\end{array}$ & Co-impregnation method & $\begin{array}{l}\mathrm{Pt}_{3} \text { Co phase identified by } \\
\text { XRD }\end{array}$ & 162 & $120-160^{\circ} \mathrm{C}$ \\
\hline Lopez et al., 2016 & 1.4\%PtCoOx/ETS-10 & $\begin{array}{l}\text { PtCoOx NPs synthesized by } \\
\text { sequential chemical wet reduction of } \\
\text { Co and Pt salts, followed by incipient } \\
\text { wetness impregnation of NPs in } \\
\text { support }\end{array}$ & $\begin{array}{l}\text { EDX analysis of Pt-Co, } \\
\text { presence of both metals. } \\
\text { Absence of } \mathrm{Pt}_{3} \mathrm{Co} \text { phase } \\
\text { discarded by XRD and XPS } \\
\text { analysis }\end{array}$ & 30 & $125-150^{\circ} \mathrm{C}$ \\
\hline This work & $1.4 \% \mathrm{Pt}_{4} \mathrm{Co} / \mathrm{ETS}-10$ & $\begin{array}{l}\mathrm{Pt}_{4} \mathrm{Co} \text { NPs synthesized by pyrolysis } \\
\text { laser followed by incipient wetness } \\
\text { impregnation of NPs in support }\end{array}$ & $\begin{array}{l}\mathrm{Pt}_{3} \text { Co phase identified by } \\
\text { XRD and XPS }\end{array}$ & 30 & $125-175^{\circ} \mathrm{C}$ \\
\hline
\end{tabular}



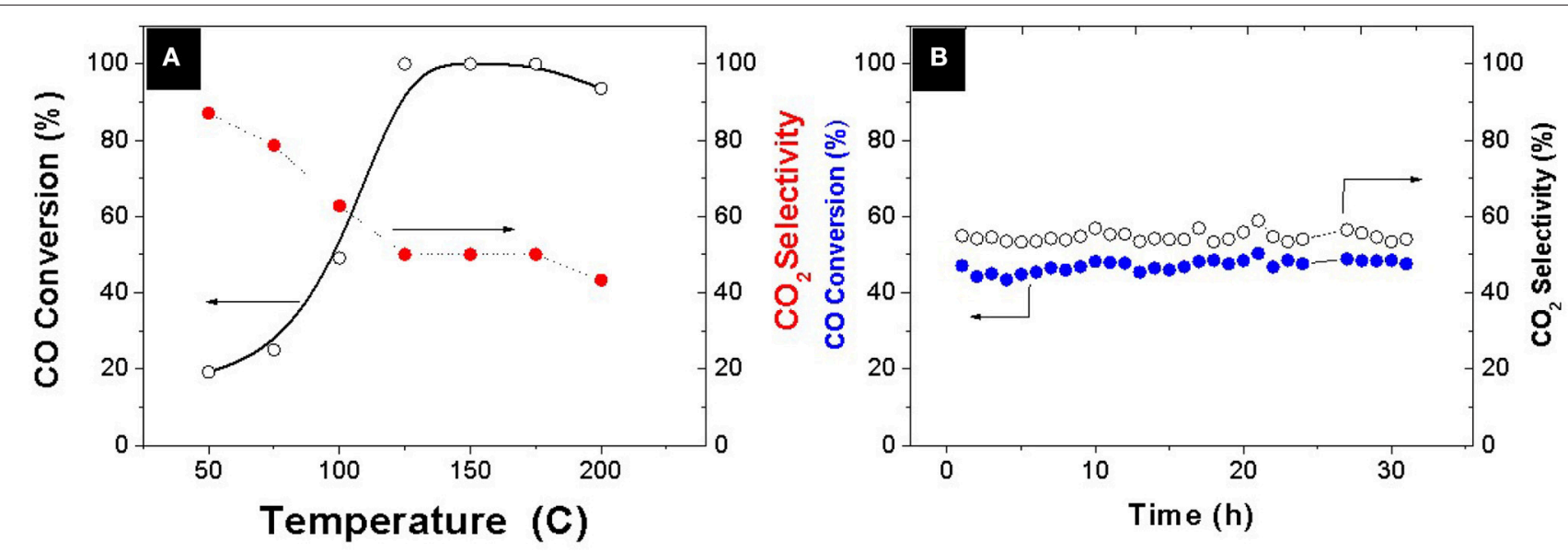

FIGURE 3 | (A) Evolution of $\mathrm{CO}$ conversion and $\mathrm{CO}_{2}$ selectivity as a function of temperature (B) Time at $\mathrm{T}=100^{\circ} \mathrm{C}$. Feed composition: $1 \% \mathrm{CO}, 1 \% \mathrm{O}{ }_{2}, 3 \% \mathrm{H}_{2} \mathrm{O}$, $21 \% \mathrm{CO}_{2}$, and $\mathrm{H}_{2}$ balance WHSW $=30 \mathrm{~L} \cdot \mathrm{g}^{-1} \cdot \mathrm{h}^{-1}$.

$40^{\circ} \mathrm{C}$, correspond to the cases where the intermetallic $\mathrm{Pt}_{3} \mathrm{Co}$ phase has been identified by XRD or XRD and XPS. In our previous work (Lopez et al., 2016) we synthesized NPs by successive chemical impregnation at low temperature, where the intermetallic phase was discarded by XRD and XPS analysis. The bimetallic NPs consist of $\mathrm{CoO}_{\mathrm{x}}$ on the surface of $\mathrm{Pt}$, and the high activity at low temperature was associated to the presence of cobalt oxides that act as an oxygen reservoir. Oxygen is supplied by the reducible oxides to the CO adsorbed on the surface and the adsorption of oxygen on the surface, which is proposed as rate determining step in the case of non-promoted Pt catalysts, it is not necessary. However, the conversion in this work at a temperature as low as $50^{\circ} \mathrm{C}$, is slightly higher, $20 \%$ compared to $12 \%$ (Lopez et al., 2016) at the same WHSV and similar metal load 1.4wt.\%. Thus, the geometric effect associated to the $\mathrm{Pt}_{3} \mathrm{Co}$ alloy, widening the Pt$\mathrm{Pt}$ atomic distance and electron transfer from $\mathrm{Pt}$ to $\mathrm{Co}$, has lower sensitivity to temperature. The experimental results obtained in the present work remark the importance of the alloy formation in the catalytic results, increasing the activity of the catalyst, and widening the temperature operation window. Finally, the catalyst stability was tested for $30 \mathrm{~h}$ (Figure 3B) and no deactivation was observed.

Analogous wide temperature windows in PROX have been only reported when bimetallic alloy nanoparticles are present. Wang et al. (2013) prepared a PtCo catalyst (4\%wt.) supported on $\mathrm{AlPO}_{4}$ and reported the complete removal of CO, in a simulated reformate stream at temperatures ranging from 80 to $130^{\circ} \mathrm{C}$ working at $30 \mathrm{~L} \mathrm{~g}^{-1} \mathrm{~h}^{-1}$ with an optimized catalyst containing a load of Pt as high as 4 and $0.7 \%$ Co supported on carbon nanotubes. Recently Furukawa et al. (2016) also reported a wide temperature window 90 to $160^{\circ} \mathrm{C}$ with a catalyst $3 \mathrm{wt} . \% \mathrm{Pt}, \mathrm{Pt}_{3} \mathrm{Co}$ supported in $\mathrm{MgO}$ at $162 \mathrm{~L} \mathrm{~g}^{-1} \mathrm{~h}^{-1}$ without the presence of $\mathrm{CO}_{2}$ and $\mathrm{H}_{2} \mathrm{O}$.

\section{CONCLUSIONS}

In summary, carbon-encapsulated alloy nanoparticles $\left(\mathrm{Pt}_{\mathrm{x}} \mathrm{Co}_{\mathrm{y}} / \mathrm{C}\right)$ have been successfully synthesized with controllable composition by a facile one-pot laser-assisted method. The carbon encapsulation strategy not only allows to prepare stable and well-dispersed bimetallic nanoparticles $<3 \mathrm{~nm}$ in size, but also prevents nanoparticles from agglomeration. The as-prepared $\mathrm{Pt}_{4} \mathrm{Co} / \mathrm{C}$ catalyst has exhibited superior activity for the oxidation of $\mathrm{CO}$ in a simulated reformate gas stream. The solid containing 1.5 wt.\% of nanoparticles can achieve complete CO conversion in a wide temperature window range of 125 to $175^{\circ} \mathrm{C}$ working at WHSV $=30 \mathrm{~L} \mathrm{~h}^{-1} \mathrm{~g}^{-1}$. The stability of this solid was tested for $30 \mathrm{~h}$, showing no changes in CO conversion or selectivity. This work offers not only an important strategy to prepare stable Pt-Co bimetallic nanoparticles, but also provides an innovative alternative for the synthesis of high-performance catalysts, which may enable a wide variety of potentials applications in many fields, such as catalytic electrodes in the oxygen evolution reaction ORR.

\section{AUTHOR CONTRIBUTIONS}

GM, AM, RM, and JS designed the experiments. GM, AM, and $\mathrm{AL}$ performed the reaction experiments. JLH contributed in the characterization. GM, AM, and AL designed and performed the experimental setup to determine the catalytic activity. GM, $\mathrm{RM}$, and JS co-wrote the manuscript with the contribution and approval of all the authors.

\section{ACKNOWLEDGMENTS}

Financial support from MINECO (Spain) and the CIBERBBN (initiative funded by the VI National R\&D\&i Plan 20082011, Iniciativa Ingenio 2010, Consolider Program, CIBER Actions and financed by the Instituto de Salud Carlos III with assistance from the European Regional Development Fund) is gratefully acknowledged. The synthesis of materials has been performed by the Platform of Production of Biomaterials and Nanoparticles of the NANOBIOSIS ICTS, more specifically by the Nanoparticle Synthesis Unit of the CIBER in BioEngineering, Biomaterials \& Nanomedicine (CIBER-BBN). The microscopy works have been conducted in the Laboratorio de Microscopias 
Avanzadas at Instituto de Nanociencia de Aragon-Universidad de Zaragoza. Authors acknowledge the LMA-INA for offering access to their instruments and expertise. Authors thank Sr. Silvia Irusta for many helpful discussions and for performing the XPS measurements.

\section{REFERENCES}

Antolini, E. (2003). Formation of carbon-supported PtM alloys for low temperature fuel cells: a review. Mater. Chem. Phys. 78, 563-573. doi: 10.1016/S0254-0584(02)00389-9

Arbizzani, C., Righi, S., Soavi, F., and Mastragostino, M. (2011). Graphene and carbon nanotube structures supported on mesoporous xerogel carbon as catalysts for oxygen reduction reaction in protonexchange-membrane fuel cells. Int. J. Hydrogen Energy 36, 5038-5046. doi: 10.1016/j.ijhydene.2011.01.083

Arico, A. S., Poltarzewski, Z., Kim, H., Morana, A., Giordano, N., and Antonucci, V. (1995). Investigation of a carbon-supported quaternary pt-rusn-w catalyst for direct methanol fuel-cells. J. Power Sources 55, 159-166. doi: 10.1016/0378-7753(94)02178-6

Arico, A. S., Shukla, A. K., Kim, H., Park, S., Min, M., and Antonucci, V. (2001). An XPS study on oxidation states of Pt and its alloys with Co and Cr and its relevance to electroreduction of oxygen. Appl. Surf. Sci. 172, 33-40. doi: 10.1016/S0169-4332(00)00831-X

Bardi, U., Beard, B. C., and Ross, P. N. (1990). CO chemisorption on the 111 and 100 oriented single-crystal surfaces of the alloy $\mathrm{CoPt}_{3}$. J. Catal. 124, 22-29. doi: 10.1016/0021-9517(90)90100-X

Ferrari, A. C. (2007). Raman spectroscopy of graphene and graphite: Disorder, electron-phonon coupling, doping and nonadiabatic effects. Solid State Commun. 143, 47-57. doi: 10.1016/j.ssc.2007.03.052

Furukawa, S., Ehara, K., and Komatsu, T. (2016). Unique reaction mechanism of preferential oxidation of $\mathrm{CO}$ over intermetallic $\mathrm{Pt}_{3} \mathrm{Co}$ catalysts: surface$\mathrm{OH}$-mediated formation of a bicarbonate intermediate. Catal. Sci. Technol. 6, 1642-1650. doi: 10.1039/C5CY01652E

Furukawa, S., and Komatsu, T. (2017). Intermetallic compounds: promising inorganic materials for well-structured and electronically modified reaction environments for efficient catalysis. ACS Catal. 7, 735-765. doi: 10.1021/acscatal.6b02603

Ghimbeu, C. M., Sopronyi, M., Sima, F., Delmotte, L., Vaulot, C., Zlotea, C., et al. (2015). One-pot laser-assisted synthesis of porous carbon with embedded magnetic cobalt nanoparticles. Nanoscale 7, 10111-10122. doi: 10.1039/C5NR01687H

Han, C., Bo, X. J., Zhang, Y. F., Li, M., Nsabimana, A., and Guo, L. P. (2015). Ndoped graphitic layer encased cobalt nanoparticles as efficient oxygen reduction catalysts in alkaline media. Nanoscale 7, 5607-5611. doi: 10.1039/C4NR0 $7571 \mathrm{D}$

Huang, H. H., Hu, X. L., Zhang, J. B., Su, N., and Cheng, J. X. (2017). Facile fabrication of platinum-cobalt alloy nanoparticles with enhanced electrocatalytic activity for a methanol oxidation reaction. Sci. Rep. 7:45555. doi: $10.1038 /$ srep45555

Huang, Q. H., Yang, H., Tang, Y. W., Lu, T. H., and Akins, D. L. (2006). Carbon-supported Pt-Co alloy nanoparticles for oxygen reduction reaction. Electrochem. commun. 8, 1220-1224. doi: 10.1016/j.elecom.2006.05.027

Hueso, J. L., Caballero, A., Ocana, M., and Gonzalez-Elipe, A. R. (2008). Reactivity of lanthanum substituted cobaltites toward carbon particles. J. Catal. 257, 334-344. doi: 10.1016/j.jcat.2008.05.012

Jang, J. H., Kim, J., Lee, Y., H., Kim, I., Y., Park, M., H., et al. and Kwon, Y., U. (2011). One-pot synthesis of core shell-like $\mathrm{Pt}_{3} \mathrm{Co}$ nanoparticle electrocatalyst with Pt-enriched surface for oxygen reduction reaction in fuel cells. Energy Environ. Sci. 4, 4947-4953. doi: 10.1039/clee01825f

Jiang, S. J., Ma, Y., W., Jian, G., Q., Tao, H., S., Wang, X., Z., et al. and Chen, Y. (2009). Facile construction of $\mathrm{Pt}-\mathrm{Co} / \mathrm{CNx}$ nanotube electrocatalysts and their application to the oxygen reduction reaction. Adv. Mater. 21, 4953-4956. doi: 10.1002/adma.200900677.

\section{SUPPLEMENTARY MATERIAL}

The Supplementary Material for this article can be found online at: https://www.frontiersin.org/articles/10.3389/fchem. 2018.00487/full\#supplementary-material

Jimenez, V. M., Fernandez, A., Espinos, J. P., and Gonzalezelipe, A. R. (1995). The state of the oxygen at the surface of polycrystalline cobalt oxide. J. Electron Spectros. Relat. Phenom. 71, 61-71. doi: 10.1016/0368-2048(94)02238-0

Kang, J., Li, O. L., and Saito, N. (2013). A simple synthesis method for nanometal catalyst supported on mesoporous carbon: the solution plasma process. Nanoscale 5, 6874-6882. doi: 10.1039/c3nr01229h

Ko, E. Y., Park, E. D., Lee, H. C., Lee, D., and Kim, S. (2007). Supported Pt-Co catalysts for selective $\mathrm{CO}$ oxidation in a hydrogen-rich stream. Angew. Chem. Int. Edn. 46, 734-737. doi: 10.1002/anie.200603144

Komatsu, T., and Tamura, A. (2008). $\mathrm{Pt}_{3} \mathrm{Co}$ and $\mathrm{PtCu}$ intermetallic compounds: promising catalysts for preferential oxidation of $\mathrm{CO}$ in excess hydrogen. $J$. Catal. 258, 306-314. doi: 10.1016/j.jcat.2008.06.030

Lin, P. A., and Sankaran, R. M. (2011). Plasma-assisted dissociation of organometallic vapors for continuous, gas-phase preparation of multimetallic nanoparticles. Angew. Chem. Int. Edn. 50, 10953-10956. doi: 10.1002/anie.201101881

Liu, K., Wang, A. Q., and Zhang, T. (2012). Recent advances in preferential oxidation of CO reaction over platinum group metal catalysts. ACS Catal. 2, 1165-1178. doi: 10.1021/cs200418w

Liu, X. J., Zhou, Y. C., Zhou, W. J., Li, L. G., Huang, S. B., and Chen, S. W. (2015). Biomass-derived nitrogen self-doped porous carbon as effective metal-free catalysts for oxygen reduction reaction. Nanoscale 7, 6136-6142. doi: 10.1039/C5NR00013K

Lopez, A., Navascues, N., Mallada, R., and Irusta, S. (2016). Pt-CoOx nanoparticles supported on ETS-10 for preferential oxidation of CO reaction. Appl. Catal. 528, 86-92. doi: 10.1016/j.apcata.2016.09.018

Malumbres, A., Martinez, G., Hueso, J. L., Gracia, J., Mallada, R., and Santamaria, J. (2015). Facile production of stable silicon nanoparticles: laser chemistry coupled to in situ stabilization via room temperature hydrosilylation. Nanoscale 7, 8566-8573. doi: 10.1039/C5NR01031D

Malumbres, A., Martinez, G., Mallada, R., Hueso, J. L., Bomati-Miguel, O., and Santamaria, J. (2013). Continuous production of iron-based nanocrystals by laser pyrolysis. Effect of operating variables on size, composition and magnetic response. Nanotechnology 24:325603. doi: 10.1088/0957-4484/24/32/325603

Martínez, G., Malumbres, A., Mallada, R., Hueso, J. L., Irusta, S., and Santamaria, J. (2012). Use of a polyol liquid collection medium to obtain ultrasmall magnetic nanoparticles by laser pyrolysis. Nanotechnology 23:425605. doi: 10.1088/0957-4484/23/42/425605

Min, M. K., Cho, J. H., Cho, K. W., and Kim, H. (2000). Particle size and alloying effects of Pt-based alloy catalysts for fuel cell applications. Electrochim. Acta 45, 4211-4217. doi: 10.1016/S0013-4686(00)00553-3

Munoz, E., Ruiz-Gonzalez, M. L., Seral-Ascaso, A., Sanjuan, M. L., GonzalezCalbet, J. M., de la Fuente, et al. (2010). Tailored production of nanostructured metal/carbon foam by laser ablation of selected organometallic precursors. Carbon 48, 1807-1814. doi: 10.1016/j.carbon.2010.01.025

Owen, E. A., and Jones, D. M. (1954). Effect of grain size on the crystal structure of cobalt. Proc. Phys. Soc. B 67:456.

Rodriguez, P., Tichelaar, F. D., Koper, M. T. M., and Yanson, A. I. (2011). Cathodic corrosion as a facile and effective method to prepare clean metal alloy nanoparticles. J. Am. Chem. Soc. 133, 17626-17629. doi: 10.1021/ja208264e

Saedy, S., Palagin, D., Safonova, O., van Bokhoven, J. A., Khodadadi, A. A., and Mortazavi, Y. (2017). Understanding the mechanism of synthesis of Pt3Co intermetallic nanoparticles via preferential chemical vapor deposition. J. Mater. Chem. A 5, 24396-24406. doi: 10.1039/C7TA06737B

Salgado, J. R. C., Antolini, E., and Gonzalez, E. R. (2005). Carbon supported Pt-Co alloys electrocatalysts for as methanol-resistant oxygenreduction direct methanol fuel cells. Appl. Catal. B Environ. 57, 283-290. doi: 10.1016/j.apcatb.2004.11.009 
Santiago, E. I., Varanda, L. C., and Villullas, H. M. (2007). Carbon-supported Pt-Co catalysts prepared by a modifled polyol process as cathodes for PEM fuel cells. J. Phys. Chem. C 111, 3146-3151. doi: 10.1021/jp0670081

Senkan, S., Kahn, M., Duan, S., Ly, A., and Leidhom, C. (2006). High-throughput metal nanoparticle catalysis by pulsed laser ablation. Catal. Today 117, 291-296. doi: 10.1016/j.cattod.2006.05.051

Seral-Ascaso, A., Garriga, R., Sanjuan, M. L., Razal, J. M., Lahoz, R., et al. (2013). Laser chemistry' synthesis, physicochemical properties, and chemical processing of nanostructured carbon foams. Nanoscale Res. Lett. 8:233. doi: $10.1186 / 1556-276 \mathrm{X}-8-233$

Service, R. F. (2002). Fuel Cells: Shrinking fuel cells promise power in your pocket. Science 296, 1222-1224. doi: 10.1126/science.296.5571.1222

Shukla, A. K., Arico, A. S., El-Khatib, K. M., Kim, H., Antonucci, P. L., and Antonucci, V. (1999). An X-ray photoelectron spectroscopic study on the effect of $\mathrm{Ru}$ and $\mathrm{Sn}$ additions to platinised carbons. Appl. Surf. Sci. 137, 20-29. doi: 10.1016/S0169-4332(98)00483-8

Snytnikov, P. V., Yusenko, K. V., Korenev, S. V., Shubin, Y. V., and Sobyanin, V. A. (2007). Co-Pt bimetallic catalysts for the selective oxidation of carbon monoxide in hydrogen-containing mixtures. Kinetics Catal. 48, 276-281. doi: 10.1134/S0023158407020127

Stamenkovic, V. R., Mun, B. S., Arenz, M., Mayrhofer, K. J. J., Lucas, C. A., and Markovic, N. M. (2007). Trends in electrocatalysis on extended and nanoscale Pt-bimetallic alloy surfaces. Nat. Mater. 6, 241-247. doi: 10.1038/nmat1840

Strobel, R., Grunwaldt, J. D., Camenzind, A., Pratsinis, S. E., and Baiker, A. (2005). Flame-made alumina supported Pd-Pt nanoparticles: Structural properties and catalytic behavior in methane combustion. Catal. Lett. 104, 9-16. doi: $10.1007 /$ s10562-005-7429-y

Swanson, H. E., and Eleanor, T. (1953). Circular of the Bureau of Standards no. 539 volume 1: standard X-ray diffraction powder patterns. Nat. Bureau Standards Circular 1:539.

Takenaka, S., Hirata, A., Tanabe, E., Matsune, H., and Kishida, M. (2010). Preparation of supported Pt-Co alloy nanoparticle catalysts for the oxygen reduction reaction by coverage with silica. J. Catal. 274, 228-238. doi: 10.1016/j.jcat.2010.07.005

Tamizhmani, G., and Capuano, G. A. (1994). Improved electrocatalytic oxygen reduction performance of platinum ternary alloy-oxide in solid-polymerelectrolyte fuel-cells. J. Electrochem. Soc. 141, 968-975. doi: 10.1149/1.2054866

Tao, F., Zhang, S. R., Nguyen, L., and Zhang, X. Q. (2012). Action of bimetallic nanocatalysts under reaction conditions and during catalysis: evolution of chemistry from high vacuum conditions to reaction conditions. Chem. Soc. Rev. 41, 7980-7993. doi: 10.1039/c2cs35185d

Vinayan, B. P., Jafri, R. I., Nagar, R., Rajalakshmi, N., Sethupathi, K., and Ramaprabhu, S. (2012). Catalytic activity of platinum-cobalt alloy nanoparticles decorated functionalized multiwalled carbon nanotubes for oxygen reduction reaction in PEMFC. Int. J. Hydrogen Energy 37, 412-421. doi: 10.1016/j.ijhydene.2011.09.069

Vonhoene, J., Charles, R. G., and Hickam, W. M. (1958). Thermal decomposition of metal acetylacetonates mass spectrometer studies. J. Phys. Chem. 62, 1098-1101. doi: 10.1021/j150567a019

Wang, C. X., Zhang, L. H., and Liu, Y. T. (2013). Aluminumphosphate molecular sieves supported Pt-Co catalysts for the preferential oxidation of CO in H-2-rich gases. Applied Catalysis B-Environmental 136: 48-55. doi: 10.1016/j.apcatb.2013.02.001

Wang, D. S., and Li, Y. D. (2011). Bimetallic nanocrystals: liquidphase synthesis and catalytic applications. Adv. Mater. 23, 1044-1060. doi: 10.1002/adma.201003695
Wang, G. H., Hilgert, J., Richter, F. H., Wang, F., Bongard, H. J., and Schuth, F. (2014). Platinum-cobalt bimetallic nanoparticles in hollow carbon nanospheres for hydrogenolysis of 5-hydroxymethylfurfural. Nat. Mater. 13, 294-301. doi: $10.1038 /$ nmat3872

Wang, L. P., Leconte, Y., Feng, Z. X., Wei, C., Zhao, Y., and Xu, Z. J. (2017). Novel preparation of $\mathrm{N}$-doped $\mathrm{SnO}_{2}$ nanoparticles via laser-assisted pyrolysis: demonstration of exceptional lithium storage properties. Adv. Mater. 29:1603286. doi: 10.1002/adma.201603286

Xia, B. Y., Wu, H. B., Li, N., Yan, Y., Lou, X. W., and Wang, X. (2015). One-pot synthesis of Pt-Co alloy nanowire assemblies with tunable composition and enhanced electrocatalytic properties. Angew. Chem. Int. Edn. 54, 3797-3801. doi: 10.1002/anie.201411544

Xiong, L., Kannan, A. M., and Manthiram, A. (2002). Pt-M (M = Fe, $\mathrm{Co}, \mathrm{Ni}$ and $\mathrm{Cu}$ ) electrocatalysts synthesized by an aqueous route for proton exchange membrane fuel cells. Electrochem. commun. 4, 898-903. doi: 10.1016/S1388-2481(02)00485-X

Xiong, L., and Manthiram, A. (2005). Nanostructured Pt-M/C (M = Fe and Co) catalysts prepared by a microemulsion method for oxygen reduction in proton exchange membrane fuel cells. Electrochim. Acta 50, 2323-2329. doi: 10.1016/j.electacta.2004.10.046

Xiong, L. F., and Manthiram, A. (2004). Influence of atomic ordering on the electrocatalytic activity of Pt-Co alloys in alkaline electrolyte and proton exchange membrane fuel cells. J. Mater. Chem. 14, 1454-1460. doi: 10.1039/B400968C

Yan, J., Ma, J. X., Cao, P., and Li, P. (2004). Preferential oxidation of CO in H-2rich gases over Co-promoted Pt-gamma-Al2O3 catalyst. Catal. Lett. 93, 55-60. doi: 10.1023/B:CATL.0000016949.72039.38

Yu, W. T., Porosoff, M. D., and Chen, J. G. G. (2012). Review of Pt-based bimetallic catalysis: from model surfaces to supported catalysts. Chem. Rev. 112, 5780-5817. doi: 10.1021/cr300096b

Zheng, J. N., He, L. L., Chen, C., Wang, A. J., Ma, K. F., and Feng, J. J. (2014a). One-pot synthesis of platinum(3)cobalt nanoflowers with enhanced oxygen reduction and methanol oxidation. J. Power Sources 268, 744-751. doi: 10.1016/j.jpowsour.2014.06.109

Zheng, J. N., Li, S. S., Ma, X. H., Chen, F. Y., Wang, A. J., and Feng, J. J. (2014b). Popcorn-like PtAu nanoparticles supported on reduced graphene oxide: facile synthesis and catalytic applications. J. Mater. Chem. A 2, 8386-8395. doi: 10.1039/C4TA00857J

Zignani, S. C., Antolini, E., and Gonzalez, E., R. (2008). Evaluation of the stability and durability of $\mathrm{Pt}$ and $\mathrm{Pt}-\mathrm{Co} / \mathrm{C}$ catalysts for polymer electrolyte membrane fuel cells. J. Power Sources 182, 83-90. doi: 10.1016/j.jpowsour.2008.03.061

Zsoldos, Z., and Guczi, L. (1992). Structure and catalytic activity of alumina supported platinum cobalt bimetallic catalysts.3. effect of treatment on the interface layer. J. Phys. Chem. 96, 9393-9400. doi: 10.1021/j100202a061

Conflict of Interest Statement: The authors declare that the research was conducted in the absence of any commercial or financial relationships that could be construed as a potential conflict of interest.

Copyright (c) 2018 Martinez, Malumbres, Lopez, Mallada, Hueso and Santamaria. This is an open-access article distributed under the terms of the Creative Commons Attribution License (CC BY). The use, distribution or reproduction in other forums is permitted, provided the original author(s) and the copyright owner(s) are credited and that the original publication in this journal is cited, in accordance with accepted academic practice. No use, distribution or reproduction is permitted which does not comply with these terms. 